\title{
Synthesis and Molecular Docking Study of 1-(3-Chloropropyl)- 3,5-Bis((E)-4-Methoxybenzylidene)Piperidin-4-One as Dengue Virus Type 2 (DEN2) NS2B/NS3 Protease Inhibitor Candidate
}

\author{
Romi Habibi ${ }^{1}$, Noval Herfindo ${ }^{1}$, Rudi Hendra ${ }^{1,2}$, Hilwan Y. Teruna ${ }^{1,2}$, Adel Zamri ${ }^{1,2}$ \\ ${ }^{1}$ Department of Chemistry, Faculty of Mathematics and Natural Sciences, \\ Universitas Riau, Pekanbaru, Riau, Indonesia \\ ${ }^{2}$ Scientific Consortium of Drug Discovery and Development, \\ Universitas Riau, Pekanbaru, Riau, Indonesia
}

\begin{abstract}
Curcumin is a secondary metabolite compound that has diverse biological activities. However, it is easily hydrolyzed at physiological $\mathrm{pH}$ due to the presence of the $\beta$-diketone group. Therefore, the replacement of the $\beta$-diketone group with mono ketone is expected to overcome this issue. We hereby report the synthesis of mono ketone curcumin derivatives from piperidone by two-steps reactions. The synthesis of curcumin derivate $\mathbf{3}$ was carried out by Claisen-Schmidt condensation between 4-piperidone and 4-methoxybenzaldehyde using alkaline catalyst. The synthesized curcumin derivate 3 was then reacted with the 1-bromo3-chloropropane to produce curcumin derivate 5, 1-(3-chloropropyl)-3.5-bis $((E)-4$-methoxybenzylidene)piperidin-4-one, with $72 \%$ yield. The calculated docking scores, the curcumin derivate $\mathbf{5}$ possessed a better affinity for receptors than the standard panduratin A. The curcumin derivate 5 has a lower docking score of $-6.40 \mathrm{kcal} / \mathrm{mol}$ compared to panduratin A with value of $-5.18 \mathrm{kcal} / \mathrm{mol}$ and also had strong binding interactions to DEN2 NS2B/NS3 protease. Thus, this compound is a promising candidate as a new anti-dengue agent.
\end{abstract}

Keywords : curcumin, dengue protease inhibitor, molecular docking, DEN2 NS2B/NS3.

\section{Introduction}

Dengue virus infection is a major health problem in 112 tropical $^{1}$ and subtropical countries in Southeast Asia, the Western Pacific, Central America and South America, ${ }^{2}$ and nearly 50 million new cases occur worldwide each year. ${ }^{3}$ The number cases in Indonesia is rapidly increasing due to several reasons such as population and lack of public awareness in healthy living. ${ }^{4}$

There are four serotypes of dengue virus (DEN1, DEN2, DEN3 and DEN4), whereas dengue virus type 2 (DEN2) is the most prevalent type. ${ }^{5}$ The protease complex, consisting of non-structural protein 3 (NS3) and its cofactor (NS2B). ${ }^{6}$ The NS3 serine protease is responsible for proteolytic processing of the viral polyprotein. The binding of the NS3 serine protease to an NS2B cofactor will form NS2B-NS3 protease complex ${ }^{7}$ that is required for DEN2 viral replication. Thus, this protease may be a potential target for dengue antiviral drugs by blocking the association of NS3 protease with its protein cofactor NS2B. ${ }^{8}$

Corresponding author: Prof. Adel Zamri. Department of Chemistry, Faculty of Mathematics and Natural Sciences, Universitas Riau, Pekanbaru, Riau, Indonesia. Email:adel.zamri@lecturer.unri.ac.id

Received: 10 January 2020. Revised: 31 March 2020. Published: 6 April 2020. 
One of natural compound that has potential as an anti-dengue virus is the curcuminoid group. Curcuminoids include diarylheptanoid derivatives and are the main pigment of turmeric (Curcuma longa) and various types of genus Curcuma.

Curcumin has traditionally been used in the treatment of various diseases such as cough, diabetes, hepatitis, anti-inflammatory, rheumatism, sinusitis, ${ }^{9,10}$ antioxidants, ${ }^{11}$ anti-inflammatory, ${ }^{12}$ and antibacterial. ${ }^{13}$ Curcumin is also known to have antiviral activity. ${ }^{14-16}$ Furthermore, in vivo study showed that curcumin extract at doses of $0.147 \mathrm{mg} / \mathrm{ml}$ has antiviral effect against DEN2 and reduce viremia period. ${ }^{17}$

Apart from the diverse biological activities, the bioavailability of curcumin is very low due its rapid hydrolysis to become inactive metabolites and excreted from the body. This is due to the presence of unstable beta-diketone groups at physiological $\mathrm{pH} .{ }^{18}$ Therefore, synthesis of curcumin derivatives for replacement of the beta-diketones with mono ketone is expected to overcome this.

In previous study, several mono ketone curcumin derivatives from acetone, cyclopentanone and cyclohexanone have been synthesized to increase their stability, activity and selectivity. ${ }^{19-21}$ Recently, researchers have put their interest to curcumin derivatives from piperidone due to their broad structure variations and spectrum of bioactivity, including as antiviral. ${ }^{22-24}$ However, curcumin derivatives with the modification of amine group in 4-piperidon as anti-dengue agent only few has been reported.

Accordingly, our effort was to synthesis curcumin derivatives from $N$-substituted piperidonebyusing 1-bromo-3-chloropropane as alkylating agent to the amine group and determined for their affinity to inhibit the dengue virus type 2 against NS2B/NS3 protease through molecular docking studies.

\section{Material and Methods \\ Materials}

UV-Visible spectrophotometer (Genesys 10S UV-VIS v4.002 2L9N175013), IR spectrophotometer (Shimadzu FTIR, IR Prestige-21), HPLC (Shimadzu UFLC Solution), NMR spectroscopy (Agilent $500 \mathrm{MHz}$ ), and glassware commonly used in synthesis laboratories. The starting materials used in this study were synthesis reagent grade $(\geq 98 \%)$ includes 4-piperidone monohydrate hydrochloride (Sigma-Aldrich), 4-methoxybenzaldehyde (Sigma-Aldrich), 1-bromo-3-chloropropane (Sigma-Aldrich), cesium carbonate (SigmaAldrich), absolute ethanol (Merck), sodium hydroxide (Merck), hydrochloric acid 37\% (Merck), universal indicator (Merck), GF254 TLC plates (Merck), aqua DM, absolute ethanol (Merck), and organic solvents.

\section{Synthesis Procedure}

Synthesis of 3,5-bis((E)-4-methoxy benzylidine) piperidine-4-one (3):

The synthesis of curcumin derivate $\mathbf{3}$ has been carried out by modifying the previous method. ${ }^{25}$ Compound 4-piperidone monohydrate hydrochloride $(5 \mathrm{mmol})$ and 4-methoxybenzaldehyde $(10 \mathrm{mmol})$ were dissolved in $10 \mathrm{ml}$ of absolute ethanol and 10 $\mathrm{ml}$ of $1 \mathrm{~N} \mathrm{NaOH}$ was added. Then the mixture was refluxed for 5 hours at $80{ }^{\circ} \mathrm{C}$. Reaction was monitored using TLC plate per 30 minutes. After the completion of the reaction, the mixture was neutralized using $1 \mathrm{~N} \mathrm{HCl}$. The mixture was allowed to sit overnight until a precipitate was formed. The precipitate was filtered and washed using n-hexane and aqua DM then air dried at room temperature. The obtained product was recrystallized with methanol to obtain curcumin derivate 3 . 


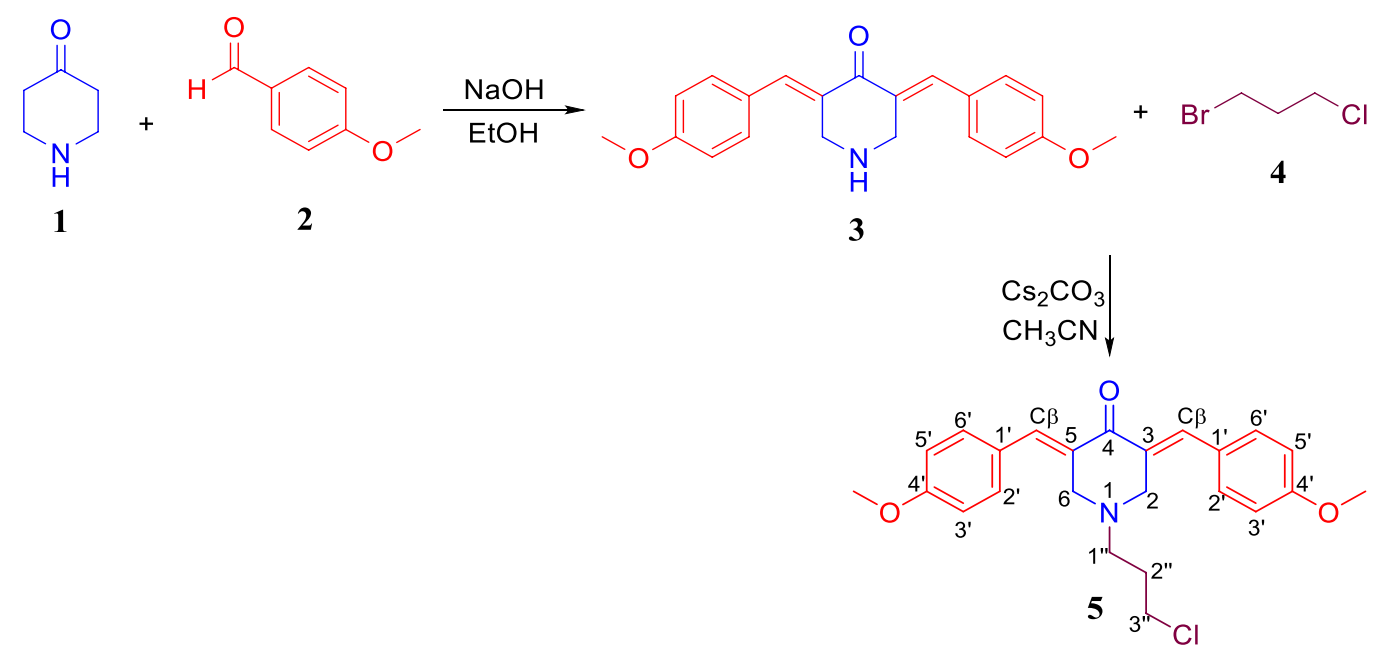

Figure 1. Protocol of The Synthesis Reaction of Curcumin Derivatives

Synthesis of 1-(3-chloropropyl)-3,5-bis((E)4-methoxybenzylidine) piperidine-4-one (5): Curcumin derivate 3 ( $1 \mathrm{mmol}$ ) was dissolved in $20 \mathrm{ml}$ of acetonitrile, then cesium carbonate ( $2 \mathrm{mmol}$ ) and 1-bromo-3-chloropropane (1.5 mmol) were added, respectively. Then the mixture was refluxed for 24 hours at $80{ }^{\circ} \mathrm{C}$. Reaction was monitored using TLC plate per 6 hours. After the completion of the reaction, the mixed reaction was cooled and concentrated using a rotary evaporator to produce a crude product. The crude product was partitioned using ethyl acetate:water system $(3 \times 15 \mathrm{ml})$. The organic layer was taken, dried with anhydrous sodium sulfate and evaporated using a rotary evaporator. The obtained product was recrystallized with methanol to obtain curcumin derivate $5 .^{26}$

\section{Molecular Docking}

The docking study was carried out using Molecular Operating Environment 2019.0101 from Chemical Computing Group Inc., (https://www.chemcomp.com). ${ }^{27}$ Molecular docking simulation was performed using ASUS E202S Netbook with Intel Celeron N3060 1.6 GHz and 2GB RAM. The crystal structure of DEN2 NS2B/NS3 Protease (PDB ID: 2FOM) was downloaded from
Protein Data Bank (https://www.rcsb.org/ structure/2FOM). The receptor protein is prepared using a structure preparation wizard. Then, the protein was energy minimized by using AMBER14:EHT force field. Ligand compounds, curcumin derivate $\mathbf{5}$ was prepared using the same method, Panduratin A (PubChem ID: 6483648) was used as positive control. The docking site was set up using the site finder feature from MOE around His51, Asp75, and Ser135 amino acids residues. The ligand was synthesized using the initial scoring methodology (London $\mathrm{dG}$ ) and the final scoring methodology (GBVI/ WSA) by placement using the Triangle Matcher protocol and post-placement refinement was Rigid Receptor. The lowest bond energy conformation was taken and visualized using the BIOVIA Discovery Visualizer 2019 for further analysis.

\section{Results and Discussion}

The synthesis of targeted curcumin compound was carried out through two-steps reactions as shown in Figure 1. The first step was the synthesis of curcumin derivate 3 through aldol condensation between 4-piperidone monohydrate hydrochloride $\mathbf{1}$ and 4-methoxybenzaldehyde 2 . The reaction 
Table 1. NMR data of Curcumin Derivate $5\left(\mathrm{CD}_{3} \mathrm{Cl}\right) 500 \mathrm{MHz}$ for ${ }^{1} \mathrm{H}$ NMR and $125 \mathrm{MHz}$ for ${ }^{13} \mathrm{C}$ NMR

\begin{tabular}{ccc}
\hline Position & $\boldsymbol{\delta}_{\mathbf{C}}(\mathbf{p p m})$ & $\boldsymbol{\delta}_{\mathbf{H}}$ (ppm) (Multiplisity, J) \\
\hline$-\mathrm{OCH} 3$ & 55.5 & $3.85(\mathrm{~s}, 6 \mathrm{H})$ \\
2 & 55.2 & $3.83(\mathrm{~s}, 2 \mathrm{H})$ \\
3 & 131.4 & - \\
4 & 187.3 & - \\
5 & 131.4 & $3.83(\mathrm{~s}, 2 \mathrm{H})$ \\
6 & 55.2 & $7.7(\mathrm{~s}, 2 \mathrm{H})$ \\
$\mathrm{C}_{\beta}$ & 136.3 & - \\
1 & 128.1 & $7.38(\mathrm{~d}, J=8.8 \mathrm{~Hz}, 4 \mathrm{H})$ \\
2, & 132.5 & $6.96(\mathrm{~d}, J=8.8 \mathrm{~Hz}, 4 \mathrm{H})$ \\
3, & 114.3 & - \\
4 & 160.4 & $9.96(\mathrm{~d}, J=8.8 \mathrm{~Hz}, 4 \mathrm{H})$ \\
5, & 114.3 & $7.38(\mathrm{~d}, J=8.8 \mathrm{~Hz}, 4 \mathrm{H})$ \\
6, & 132.5 & $2.71(\mathrm{t}, J=6.9 \mathrm{~Hz}, 2 \mathrm{H})$ \\
$1 ”$ & 43.1 & $1.91(\mathrm{p}, J=6.6 \mathrm{~Hz}, 2 \mathrm{H})$ \\
$2 ”$ & 30.4 & $3.54(\mathrm{t}, J=6.4 \mathrm{~Hz}, 2 \mathrm{H})$ \\
\hline
\end{tabular}

is initiated by the attack of the hydroxide ion of strong base catalyst which acts as a nucleophile to the acidic $\mathrm{H} \alpha$ of the ketone compound to form the enolate ion. Enolate ions that are formed will attack the aldehydes which act as electrophiles to form $\beta$-hydroxy ketone as intermediate compounds, followed by dehydration to form curcumin derivate 3. The second step, the curcumin derivate 3 was reacted with a compound $\mathbf{4}$ to obtain curcumin derivate $\mathbf{5}$ with $72 \%$ yield. This reaction occurs between the amine group (NH) of 4-piperidone ring with 1-bromo3-chloropropane as alkylating agent. This alkylation is a simple substitution reaction, where the nitrogen atom in the amine group acts as a nucleophile, the atomic carbon (CX) in the alkylating agent as an electrophile and $\mathrm{Cs}_{2} \mathrm{CO}_{3}$ as a catalyst. The amine group that has been activated by the catalyst will attack the $\mathrm{C}-\mathrm{Br}$ carbon, followed by the release of the halogen atom to obtain the final product.
The UV spectrum of curcumin derivate 5 showed absorption at wavelength of 244 and $365 \mathrm{~nm}$ which indicated an electronic transition from orbitals $\pi \rightarrow \pi^{*}$ of the conjugated framework of curcumin derivate molecule with $\pi$ electrons are delocalized through the whole molecule. The FTIR spectrum showed transmittance at 2995 and $2960 \mathrm{~cm}-1$ revealed the presence of aromatic $\mathrm{C}-\mathrm{H}$ bonds from phenyl rings and vibrations of the aliphatic $\mathrm{C}-\mathrm{H}$ bond of the methoxy group and the piperidone ring, respectively. In addition, the presence of transmittance at 1666 and $1597 \mathrm{~cm}-1$ indicated of the $\mathrm{C}=\mathrm{O}$ and $\mathrm{C}=\mathrm{C}$ bonds from an enone group of curcumin, and $\mathrm{C}-\mathrm{O}$ bond vibration from the methoxy group at $1258 \mathrm{~cm}-1$. The absences of N-H bond in the spectrum of curcumin derivate $\mathbf{5}$, indicated the substitution reaction of $\mathrm{N}-\mathrm{H}$ group with compound $\mathbf{4}$ was successfully occured and the final product was formed. 
Table 2. Molecular Docking Result

Against the DEN2 NSB/NS3 Protease

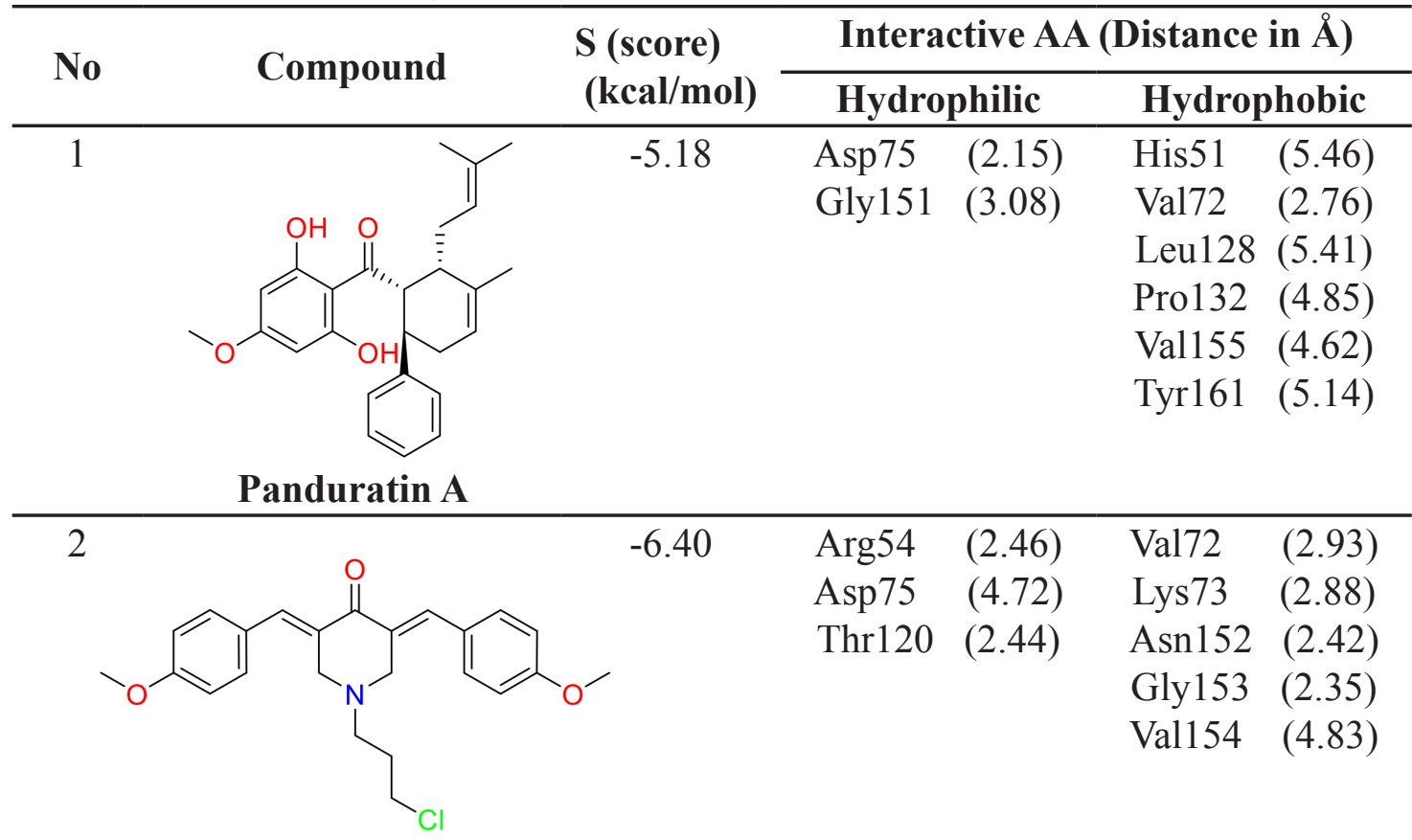

Curcumin Derivate 5

Furthermore, NMR dan HRMS spectra confirmed the curcumin derivate $\mathbf{5}$ chemical structure. ${ }^{1} \mathrm{H}$ NMR spectrum showed the presence of two set of aromatics with two substitutions and methoxy groups. In addition of 2 set of methylenes at $\delta_{\mathrm{H}} 3.83$ $(\mathrm{s}, 2 \mathrm{H})$ corresponding to piperidone unit and proton $\beta$ resonance at $\delta \mathrm{H} 7.77(\mathrm{~s}, 2 \mathrm{H})$. The presence of three methylenes at $\delta \mathrm{H} 2.71(\mathrm{t}$, $J=6.9 \mathrm{~Hz}, 2 \mathrm{H}), 1.91$ (p, $J=6.6 \mathrm{~Hz}, 2 \mathrm{H})$, and 3.54 (t, $J=6.4 \mathrm{~Hz}, 2 \mathrm{H}$ ) assigned as chloropropane unit. ${ }^{13} \mathrm{C}$ NMR spectrum revealed carbonyl ketone at $\delta_{\mathrm{C}} 187.3$ and methoxy unit at $\delta_{\mathrm{C}}$ 55.5 (Table 1). HRMS spectrum showed $[\mathrm{M}+\mathrm{H}]$ of 412.1678 corresponding to a molecular formula of $\mathrm{C}_{24} \mathrm{H}_{28} \mathrm{NO}_{3} \mathrm{Cl}$ (calcd. 412.1679 for $\mathrm{C}_{24} \mathrm{H}_{27} \mathrm{NO}_{3} \mathrm{Cl}$ ).

Molecular docking simulation of curcumin derivate 5 was performed to identify plausible binding modes to DEN2 NS2B/NS3 protease. Panduratin A was also docked as comparison, panduratin A isolated from Boesenbergia rotunda (L.) showed good inhibitory activities towards dengue-2 virus. ${ }^{17}$ The molecular docking result of curcumin derivate 5 to DEN2 NS2B/NS3 protease showed that this compound had a strong bond to the catalytic triad of the DENV protease enzyme (His51, Asp75, and Ser135). ${ }^{28}$ Panduratin A exhibited hydrophilic interactions through hydrogen bonds with Asp75 and Gly151, and hydrophobic interactions with catalytic triads, through $\pi$ stack interactions with His51 (Figure 2A). The curcumin derivate 5 demonstrated hydrophilic interaction through cationic interaction with Asp75 and through hydrogen bonding with Arg54 and Thr120, as well as hydrophobic interactions through van der Waals forces with Gly153 (Figure 2B). These amino acid residues are known to be essential in antagonistic activity against dengue virus. ${ }^{5}$ Calculated docking scores of the curcumin derivate 5 and panduratin A were $-6.40 \mathrm{kcal} /$ mol and $-5.18 \mathrm{kcal} / \mathrm{mol}$, respectively (Table 2). A lower docking score of the curcumin 

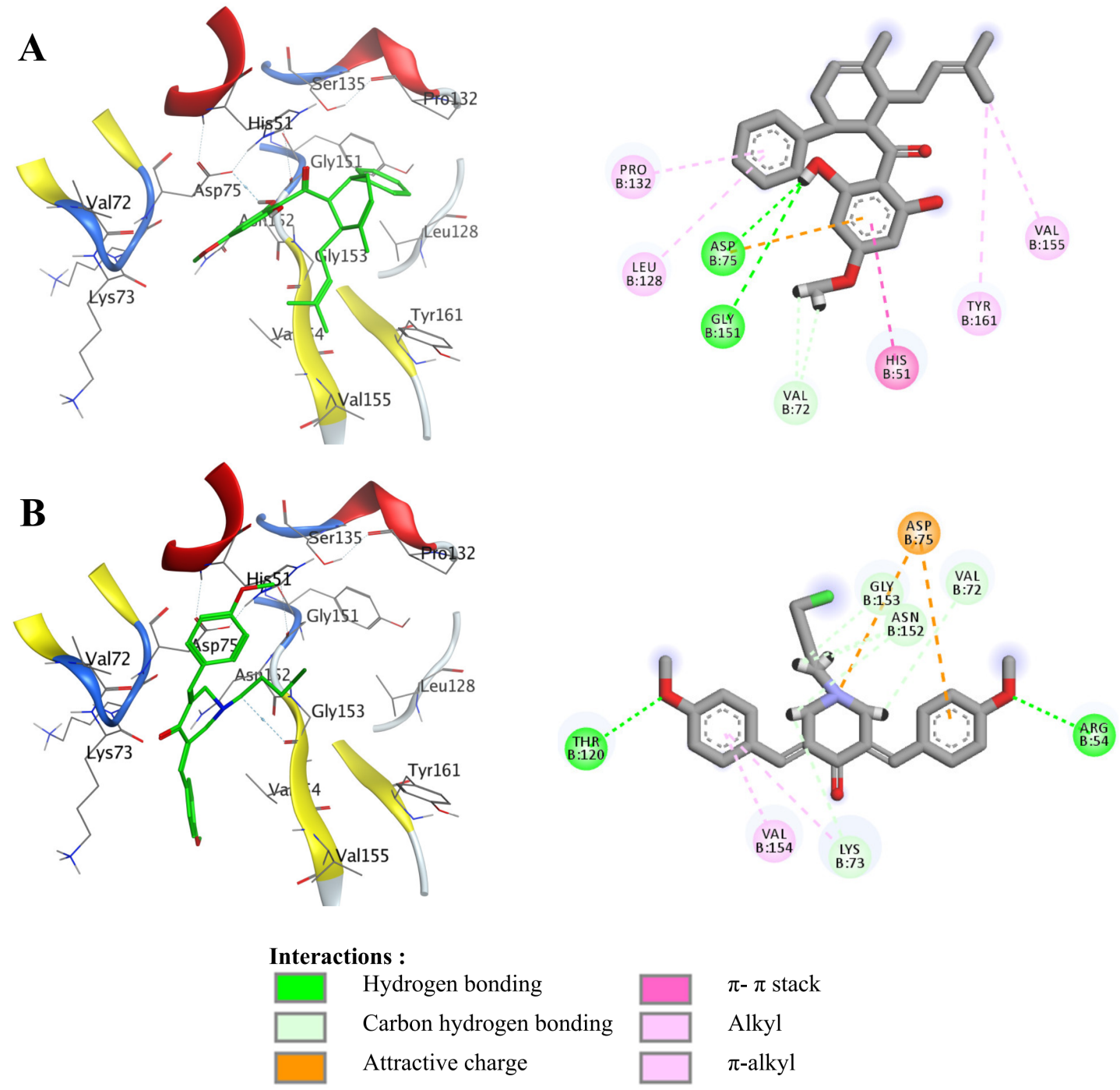

Figure 2. 2D and 3D Visualization of the Binding Mode of Panduratin A (A) and Curcumin Derivate 5 (B) Compound to the NS2B/NS3 Protease

derivate $\mathbf{5}$ compared to panduratin A and some strong interactions to the essential amino acid residues at the active site of the protease, presumably the curcumin derivate $\mathbf{5}$ showed good inhibitory activity against DEN2 NS2B/ NS3 protease.

\section{Conclusion}

The curcumin derivate $\mathbf{5}$ was successfully synthesized by two-steps reactions with $72 \%$ yield. Chemical structure of curcumin derivate $\mathbf{5}$ was confirmed by FTIR, NMR, and HRMS spectroscopy analysis. Molecular docking result showed that the compound has better affinity to the DEN2 NS2B/NS3 protease than panduratin $\mathrm{A}$ as positive control. The curcumin derivate $\mathbf{5}$ also showed strong interactions to Arg54, Asp75, and Thr120 which is essential in antagonistic activity NS2B/NS3 protease. Thus, it can be assumed that the compound is a potential candidate as a new agent in inhibiting the type 2 dengue virus.

\section{Acknowledgments}

Authors thank to all colleagues who fully supported this research. 


\section{Funding}

This study was funded by Postgraduate Research Grant from the Ministry of Research, Technology, and Higher Education of the Republic of Indonesia 2018 with contract number: 086/SP2H/LT/ DRPM/2018 and 335/UN.19.5.1.3/ PP/2018.

\section{Conflict of Interest}

None declared.

\section{References}

1. Gurugama P, Garg P, Perera J, Wijewickrama A, Seneviratne SL. Dengue viral infections. Indian Journal of Dermatology. 2010;55(1):68-78. doi:10.4103/0019-5154.60357

2. Murray NEA, Quam MB, Wilder-Smith A. Epidemiology of dengue: past, present and future prospects. Clinical Epidemiology. 2013;5:299-309.doi:10.2147/CLEP. S34440

3. Carnec X, Meertens L, Dejarnac O, Pararera-Lecoin M, Hafirassou ML, Kitaura J, Ramdasi R, Schwartz O, Amara A. The Phosphatidylserine and Phosphatidylethanolamine Receptor CD300a Binds Dengue Virus and Enhances Infection. Journal of Virology. 2015;90(1):92-102. doi:10.1128JVI.01849 $-15$

4. Almuhanna R, Alobudi A, Alazdi S, Alghamdi H, Hindi M, Ghanim A, Fakeih E, Alharbi A, Jumbi R, Banjar A. Knowledge, awareness and attitude towards dengue fever outbreaks in the summer. International Journal of Advances in Medicine. 2018;5(4). doi:10.18203/2349-3933.ijam20182957

5. Frimayanti N, Chee CF, Zain SM, Rahman NA. Design of new competitive dengue NS2B/NS3 protease inhibitors-a computational approach. International Journal of Molecular Sciences. 2011;12(2):1089-1100.doi:10.3390/ijms
12021089

6. Wu D, Mao F, Ye Y, Li J, Xu C, Luo X, Chen J, Shen X. Policresulen, a novel NS2B/ NS3 protease inhibitor, effectively inhibits the replication of DENV2 virus in BHK21 cells. Acta Pharmacologica Sinica. 2015;36(9):1126-1136. doi:10.1038/ aps. 2015.56

7. Chambers TJ, Nestorowicz A, Amberg SM, Rice CM. Mutagenesis of the yellow fever virus NS2B protein: effects on proteolytic processing, NS2B-NS3 complex formation, and viral replication. Journal of Virology. 1993;67(11):67976807.

8. Powers CN, Setzer WN. An In-Silico Investigation of Phytochemicals as Antiviral Agents Against Dengue Fever. Combinatorial Chemistry \& High Throughput Screening. 2016;19(7):516536. doi:10.2174/1386207319666160506 123715

9. Kim HY, Park EJ, Joe E, Jou I. Curcumin Suppresses Janus KinaseSTAT Inflammatory Signaling through Activation of Src Homology 2 DomainContaining Tyrosine Phosphatase 2 in Brain Microglia. The Journal of Immunology. 2003;171(11):6072 LP 6079. doi:10.4049/jimmunol.171.11.6072

10. Suzuki M, Nakamura T, IyokiS, FujiwaraA, Watanabe Y, Mohri K, Isobe K, Ono K, Yano S. Elucidation of Anti-allergic Activities of Curcumin-Related Compounds with a Special Reference to Their Anti-oxidative Activities. Biological and Pharmaceutical Bulletin.2005;28(8):1438-1443. doi:10.1248/bpb.28.1438

11. Fadus MC, Lau C, Bikhchandani J, Lynch HT. Curcumin: An age-old anti-inflammatory and anti-neoplastic agent. Journal of Traditional and Complementary Medicine. 2016;7(3):339346 doi:10.1016/ j.jtcme.2016.08.002

12. Chattopadhyay I, Biswas K, 
Bandyopadhyay U, Banerjee RK. Turmeric and curcumin: Biological actions and medicinal applications. Current Science. 2004;87(1):44-53.

13. Mathew D, Hsu W-L. Antiviral potential of curcumin. Journal of Functional Foods. 2018;40:692-699. doi:https://doi. org/10.1016/j.jff.2017.12.017

14. Anand P, Thomas SG, Kunnumakkara AB, et al. Biological activities of curcumin and its analogues (Congeners) made by man and Mother Nature. Biochemical Pharmacology. 2008;76(11):15901611. doi:https://doi.org/10.1016/j.bcp. 2008.08.008

15. Mounce BC, Cesaro T, Carrau L, Vallet T, Vignuzzi M. Curcumin inhibits Zika and chikungunya virus infection by inhibiting cell binding. Antiviral Research. 2017;142:148-157. doi:https:// doi.org/10.1016/j.antiviral.2017.03.014

16. Marbawati D, Umniyati SR. Effects of Curcumin and Pentagamavunon-0 Against Dengue-2 Virus Infection in Vero Cells; an in Vitro Study. Procedia Environmental Sciences. 2015. doi:10.1016/j.proenv. 2015.01 .033

17. Tan S, Pippen R, Yusof R, Rahman N, Ibrahim H, Khalid N. Screening of selected zingiberaceae extracts for dengue-2 virus protease inhibitory activities. Sunway Academic Journal. 2006;3:1-7.

18. Ichsyani M, Ridhanya A, Risanti M, Desti H, eria R, Putri DH, Sudiro TM, Dewi BE. Antiviral effects of Curcuma longa L. against dengue virus in vitro and in vivo. Earth and Environmental Science. 2017:110. doi:10.1088/1755-1315/101/1/012005

19. Eryanti Y, Nurulita Y, Hendra R, . Y, Syahri J, Zamri A. Synthesizing Derivatives From Cyclopentanone Analogue Curcumin and Their Toxic, Antioxidant and AntiInflammatory Activities. MAKARA of Science Series. 2012;15(2):117-123. doi:10.7454/mss.v15i2.1060
20. Adams BK, Ferstl EM, Davis MC, Herold M, Kurtkaya S, Camalier RF, Hollingshead MG, Kaur G, Sausville EA, Rickles FR, Synder JP, Liotta CD, Shoji M. Synthesis and biological evaluation of novel curcumin analogs as anti-cancer and anti-angiogenesis agents. Bioorganic \& Medicinal Chemistry. 2004;12(14):38713883. doi:https://doi.org/10.1016/j. bmc.2004.05.006

21. Da'i M, Meiyanto E, Supardjan, Jenie UA, Kawaichi M. Potensi Antiproliferative Analog Kurkumin Pentagamavunon Terhadap Sel Kanker Payudara T47D. Artocarpus. 2007;7(1):14-20.

22. Hossain M, Das S, Das U, Doroudi A, Zhu J, Dimmock JR. Novel hybrid molecules of 3,5-bis(benzylidene)-4-piperidones and dichloroacetic acid which demonstrate potent tumour-selective cytotoxicity. Bioorganic and Medicinal Chemistry Letters. 2020;30(3):126878. doi:https:// doi.org/10.1016/j.bmcl.2019.126878

23. Eryanti Y, Zamri A, Frimayanti N, et al. Synthesis, structure-activity relationship, docking and molecular dynamic simulation of curcumin analogues against HL-60 for anticancer agents (leukemia). Oriental Journal of Chemistry. 2017;33(5):21642172. doi:10.13005/ojc/330503

24. Osman H, Idris NH, Kamarulzaman EE, Wahab HA, Hassan MZ. 3,5-Bis(arylidene)-4-piperidones as potential dengue protease inhibitors. Acta Pharmaceutica Sinica B. 2017;7(4):479484. doi:10.1016/j.apsb.2017.04.009

25. Eryanti Y, Herlina T, Zamri A, et al. 3,5-Bis(2-hydroxybenzylidene)piperidin4-one. MolBank. 2014(2):3-5. doi:10.3390/ M825

26. Zamri A, Teruna HY, Rahmawati EN, Frimayanti N, Ikhtiarudin I. Synthesis and in silico studies of a benzenesulfonyl curcumin analogue as a new anti dengue virus type 2 (DEN2) NS2B/ 
NS3. Indonesian Journal of Pharmacy. 2019;30(2):84-90. doi:10.14499/

indonesianjpharm30iss2pp84

27. Herfindo N, Prasetiawati R, Sialagan D, Frimayanti N, Zamri A. Synthesis, Antiproliferative Activity and Molecular Docking Studies of 1,3,5-Triaryl Pyrazole Compound as Estrogen $\alpha$ Receptor Inhibitor Targeting MCF-7 Cell Line. Molekul. 2020;15(1):18-25. doi:https:// doi.org/10.20884/1.jm.2020.15.1.585

28. Noble CG, Seh CC, Chao AT, Shi PY. Ligand-bound structures of the dengue virus protease reveal the active conformation. Journal of Virology. 2012;86(1):438-446. doi:10.1128/JVI.06225-11 